\title{
Trace Analysis of Heavy Metals in Ground Water and Soil near Coal Based Thermal Power Plant Udupi Karnataka
}

\author{
D.O.I - 10.51201/Jusst12608 \\ http://doi.org/10.51201/Jusst12608
}

\author{
Nausha Shetty ${ }^{1}$, Jyothi K Shetty ${ }^{2}$, Dr Mohandas Chadaga*, Dr Udaya \\ Shankara $\mathrm{H} \mathrm{N}^{4}$ \\ ${ }^{1}$ Department of Civil Engineering ,Manipal Institute of Technology,Manipal \\ Academy of Higher Education, Manipal 576104 India \\ ${ }^{2}$ Department of Civil Engineering ,Manipal Institute of Technology,Manipal \\ Academy of Higher Education, Manipal 576104 India \\ ${ }^{4}$ Department of Civil Engineering ,Manipal Institute of Technology,Manipal \\ Academy of Higher Education, Manipal 576104 India
}

\begin{abstract}
The study involves evaluation of quality of groundwater and soil near the Thermal power plant located in Udupi District, Karnataka, India based on seasonal variation. 24 samples of ground water and soil were collected during Pre-Monsoon, Post-Monsoon and Monsoon Seasons from the places which are surrounding the Thermal Power plant. Collected Ground water samples were tested for detection of various heavy metal concentrations such as $\mathrm{Ni}, \mathrm{Fe}, \mathrm{Mn}, \mathrm{Cr}$, and $\mathrm{Pb}$ and soil samples were detected for $\mathrm{Ni}, \mathrm{Fe}$, $\mathrm{Mn}, \mathrm{Cr}, \mathrm{Pb}, \mathrm{Cd}$ and $\mathrm{Co}$. Collected soil samples were sieved according to different Standard sieve size. After sieving, soil samples were digested using tri-acids (Nitric Acid, Hydrogen peroxide and Concentrated Hydrochloric acid). Both Ground water and Soil samples were analysed for heavy metal contamination by using Atomic Absorptive Spectrometry. From the results obtained for Pre-Monsoon, Post-Monsoon and Monsoon Season it showed that concentration of heavy metals in the samples were exceeding the permissible limit prescribed by $\mathrm{WHO}$ and BIS. Hence preliminary treatment should be done before discharging in to Ash ponds.
\end{abstract}

Keywords: thermal power plant; ash pond; atomic absorptive spectrometry; soil digestion; heavy metal; tri-acids;

\section{Introduction}

A coal based thermal power station" located at Udupi, "Karnataka, India, established in 2008". It is situated to the north of Mangaluru, west of Belman, and to the northeast of Padubidri in the village of Yellur, Udupi district", close to the Shambavi River, roughly 7 or $8 \mathrm{~km}$ from the coast from where the imported coal for the power plant is transported to plant through rail line". "It has installed capacity of 1200 MW $(2 \times 600)$ ". "The plant became fully operational in September 2012". First Party sold the plant to the second party. In August 2014, second party has agreed to sell this power plant to third 
party. "In-spite of the assurances of maintaining the clean environment, functioning/operation of TPP since July 2010 the region experienced large scale environmental contamination (land, water, air and biotic elements) affecting the livelihood of the local people." "This led to massive agitations in the district demanding the district administration to intervene immediately to ensure safe drinking water, etc." During transportation and disposal of fly ash it gets dispersed in to the environment which results in air pollution. Dispersed fly ash gets accumulated in the leaves and other vegetation which reduces the growth and productivity of the plants. And respiratory related problems for human beings. Due to discharge of ash pond water in to the streams nearby which joins the river, thus contaminating the water sources. Due to percolation of saline water into agricultural lands which affects the yield of the paddy and also other pollutants from thermal power plant affect the paddy yield, thus reduced productivity. Disposal of synthetic material used for GRP pipeline coating contaminates soil. Due to environmental degradation which caused reduction of pollinator's pollution in the areas located around the thermal power plant.

\section{Materials and methodology}

\section{Study area}

The study area is situated to the north of Mangaluru, west of Belman and northeast of Padubidri in the village named Yellur, Udupi district, Karnataka with Latitude and Longitude of $13^{\circ} 9^{\prime} 35^{\prime \prime} \mathrm{N} 74^{\circ} 48^{\prime} 0^{\prime \prime} \mathrm{E}$. It is also close to River Shambhavi, a "tributary to river Mulki flows nearly $4 \mathrm{~km}$ south of the Yellur village". The study area includes Yellur as well as other villages such as Nandikur, Palimar, Santhukopla, Kajarakatte and also other villages.

The study area is mainly situated in between "Western Ghats in the east and Arabian Sea in the west".

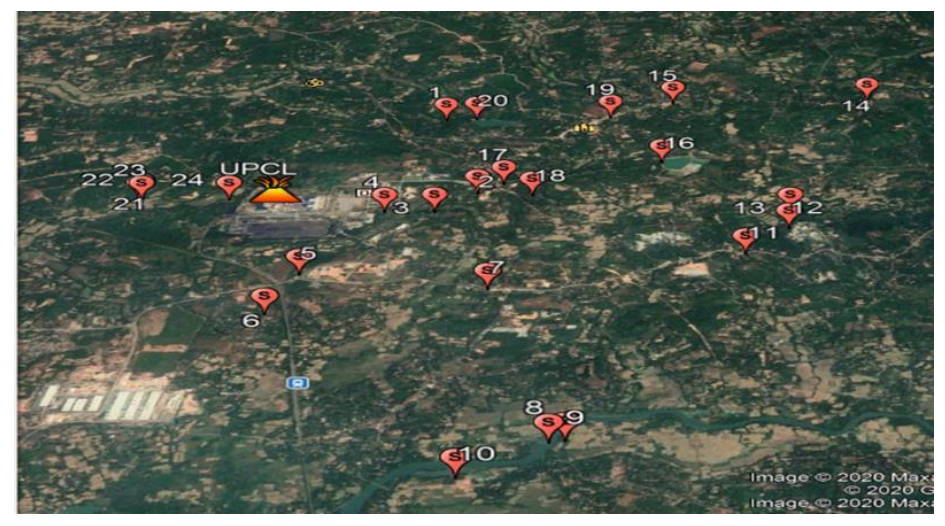

Figure No: 2.1.1 Study Area

\section{Sample collection and analysis}

Ground Water and soil samples were collected from the selected study area. We collected the samples based on the seasonal variations i.e.Pre-Monsoon, Monsoon and PostMonsoon. (Parveen Kumar et al., 2018; Manoj Kumar Tiwaria et al., 2018; S.S. Ramya et al., 2013 ;) Collected Ground water and Soil samples were analysed for heavy metal concentration using Atomic Absorptive Spectrometry (AAS).

\section{Water samples}

Ground water samples were collected from twenty four areas which are surrounding the Coal based Thermal Power Plant based on seasonal variation i.e;Pre-Monsoon,PostMonsoon and Monsoon Season. Ground water samples were collected using stainless steel bucket. Collected ground water samples were stored in poly propylene bottles. Basic water parameters were done using Hach meter such as $\mathrm{pH}$, salinity, DO, TDS, 
Resistivity, conductivity (T.V. Ramachandra et al., 2012). Collected ground water samples were filtered using Filtration Unit. For the analysis of heavy metals traces in the collected ground water samples Atomic Absorptive Spectrometry (AAS) is used. (Manoj Kumar Tiwaria et al., 2018; Chanchal Verma et al., 2017; R K Singh et al., 2014 ;)

\section{Soil Samples}

Totally 72 samples of soil were collected from the selected study area based on the seasonal variation

i.e. Pre-Monsoon, Monsoon and Post-Monsoon seasons. Collected Soil samples were sieved according to standard sieve size. Sieved soil samples were digested using tri acid method i.e.; $\mathrm{HNO}_{3}, \mathrm{H}_{2} \mathrm{O}_{2}$, $\mathrm{HCL}$ (Prashant Agrawal et al., 2010 ;). After the digestion of collected soil sample it is analysed for heavy metal concentration by using Atomic Absorptive Spectrometry(AAS).

\section{Socio-Economic Survey}

Socio economic survey involves data collection, sampling technique and sample size. Data collection involves gathering of information about sample area. A survey was conducted in localities which are nearby Coal based Thermal Power Plant. There are many sampling techniques available for conducting socio economic survey such as Stratified sampling, Random sampling, Cluster sampling, Systematic sampling etc. In this project we have applied Cluster sampling. Which is also known as area sampling. In this data or respondent will are similar in nature. Sampling units are groups rather than individuals. All of the elements within selected clusters are included in the sample. Sample size is calculated using several formulas. In this project we have adopted Sample size:

Sample size is the finding of number of respondent to be included in the sampling. Larger the samples size higher the precision of results of estimated data. Here in this project we have involved Slovin's formula for determining sample size.

$\mathrm{n}=\mathrm{N} /(1+\mathrm{Ne} 2)$

Where, $\mathrm{n}=$ Sample size

$\mathrm{N}=$ Population size

$\mathrm{e}=$ Level of precision

\section{Results and discussion}

\section{Ground Water}

Ground water samples were analysed for heavy metal concentration such as $\mathrm{Cr}, \mathrm{Fe}, \mathrm{Mg}$, $\mathrm{Ni}$ and $\mathrm{Pb}$ using Atomic Absorptive Spectrometry (AAS).From the results obtained for Pre-monsoon water samples it showed that Chromium concentration exceeds the permissible limit prescribed by WHO and BIS in all the 24 samples i.e.; $>0.05 \mathrm{mg} / \mathrm{l}$. Results of Monsoon sampling indicates that Manganese exceeds permissible limit in Santhoor (near ash pond) i.e.; $>0.3 \mathrm{mg} / \mathrm{l}$.Chromium concentration exceeds permissible limit in all the 24 samples i.e.; $>0.05 \mathrm{mg} / \mathrm{l}$.From the Post-Monsoon sampling results it showed that Chromium was exceeding the permissible limit in all the 24 samples i.e.; $>0.05 \mathrm{mg} / 1$. Manganese exceeds permissible limit in santhoor area near ash pond. Due to increase in chromium content more than drinking water standards which may cause respiratory problem, irritation in nose, asthma and cough. And also presence of high level of manganese will also leads to respiratory related disease and damage the brain. 


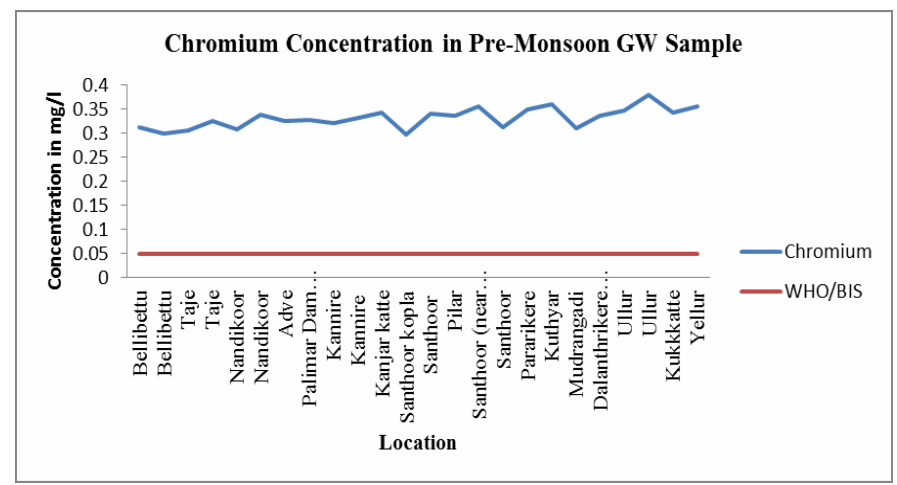

Figure No: 3.1.1 Chromium Concentrations of Pre-Monsoon GW Samples

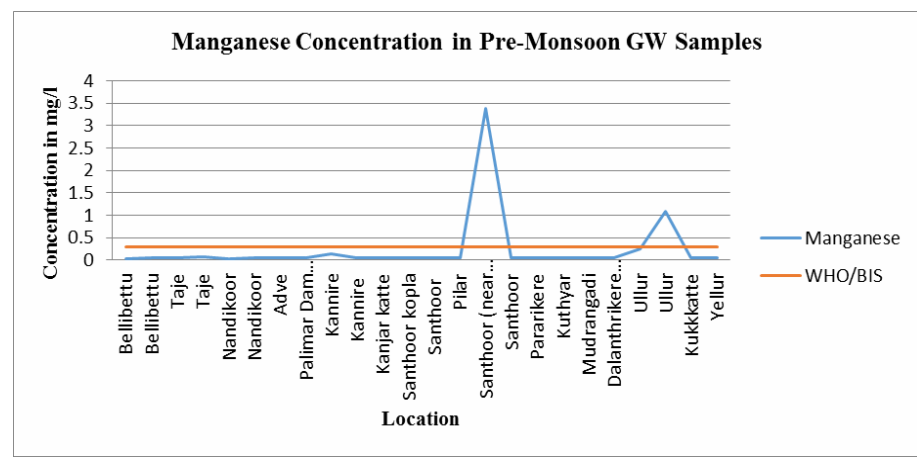

Figure No: 3.1.2Manganese Concentrations of Pre-Monsoon GW Samples

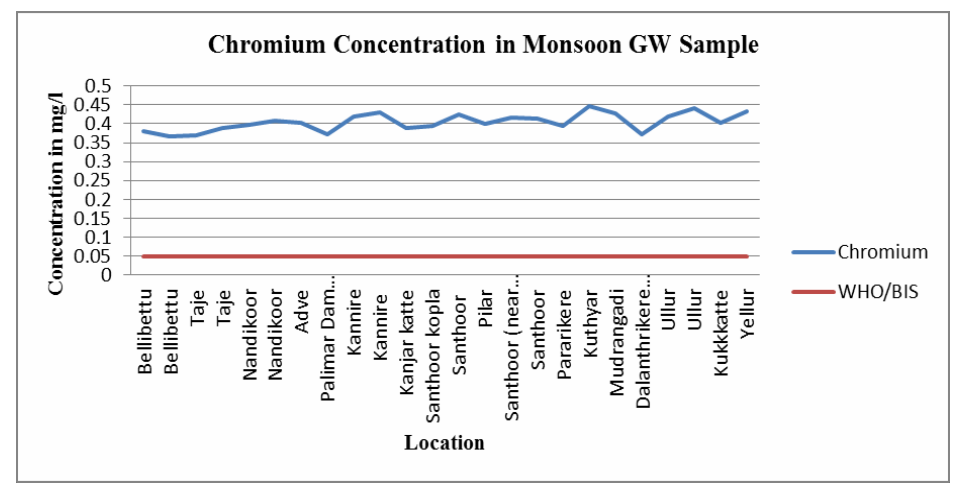

Figure No: 3.1.3 Chromium Concentrations of Monsoon GW Samples

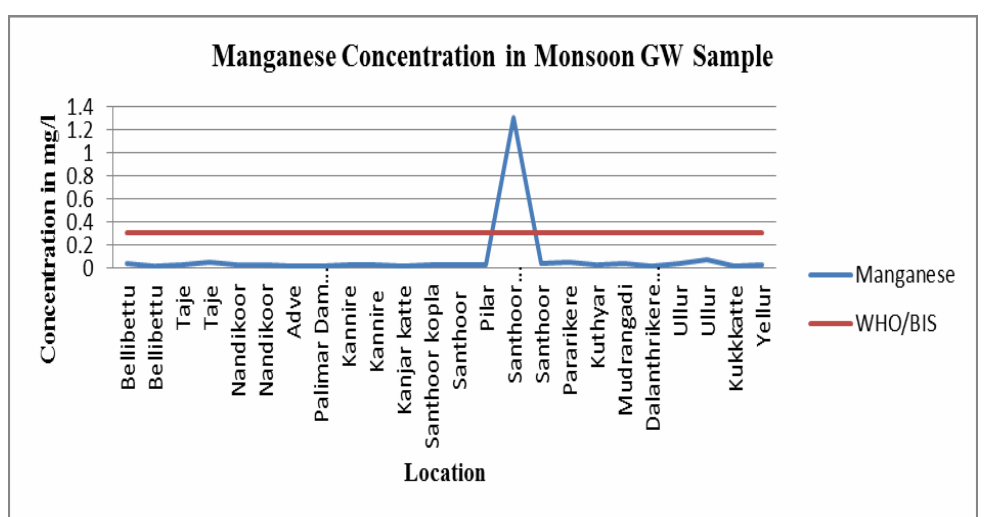

Figure No: 3.1.4 Manganese Concentrations of Monsoon GW Samples 


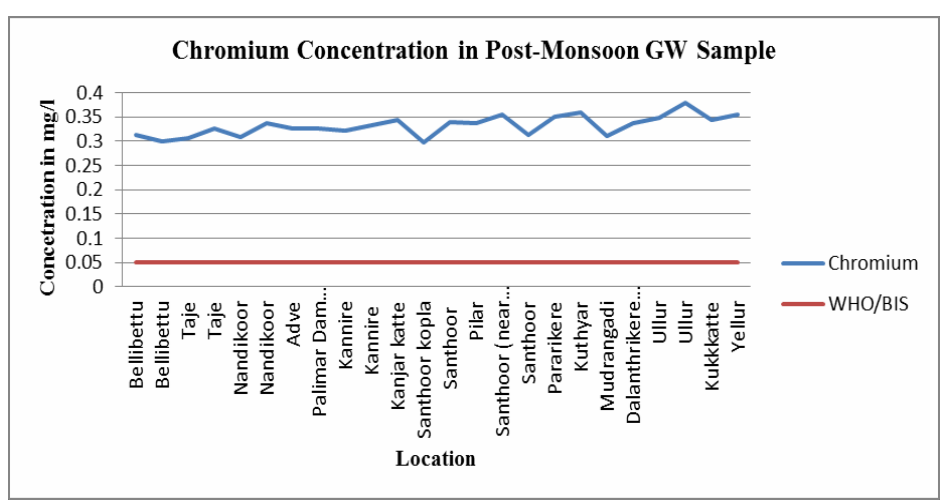

Figure No: 3.1.5 Chromium Concentrations of Post-Monsoon GW Samples

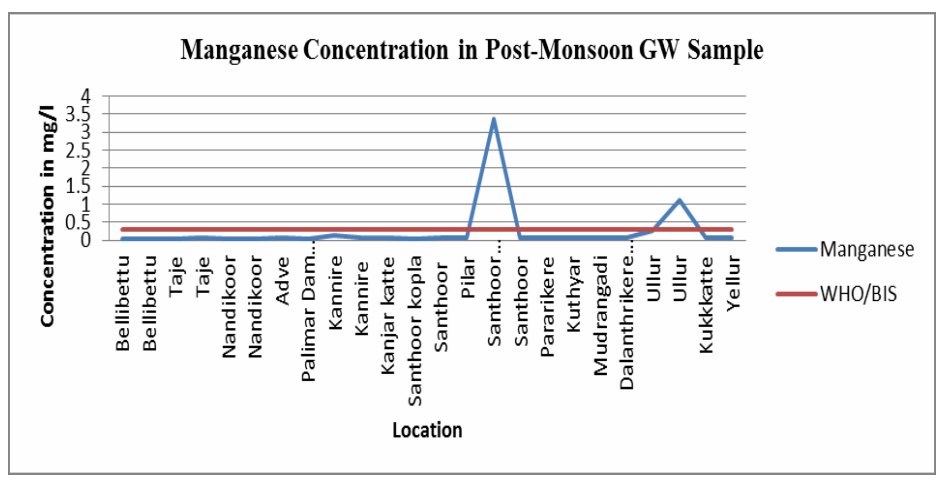

Figure No: 3.1.6 Manganese Concentrations of Post-Monsoon GW Samples

\section{Soil}

Soil Samples collected are analysed for heavy metal traces such as $\mathrm{Cr}, \mathrm{Fe}, \mathrm{Mg}, \mathrm{Ni}, \mathrm{Pb}, \mathrm{Cd}$ and Co using Atomic Absorptive Spectrometry (AAS).Results obtained from PreMonsoon soil samples showed that Chromium, Iron, Manganese and Cadmium were exceeding the permissible limit prescribed by WHO and BIS in all the 24 samples i.e.; $>0.05 \mathrm{mg} / \mathrm{l}$.Nickel concentration exceeds its permissible limit in 22 samples i.e.; $>0.02 \mathrm{mg} / \mathrm{l}$.Lead concentration exceeds its permissible limit in 20 samples i.e.; $>0.001 \mathrm{mg} / \mathrm{l}$.Cobalt exceeds its permissible limit in 21 samples i.e.; $>0.05 \mathrm{mg} / 1$. Results obtained from Monsoon soil indicates that Chromium,Iron,Manganese, Nickel were exceeding the permissible limit in all the 24 samples. Lead content exceeds its permissible limit in 23 samples i.e.; $>0.01 \mathrm{mg} / \mathrm{l}$. Whereas cobalt exceeds its permissible limit in 15 samples i.e.; $>0.05 \mathrm{mg} / \mathrm{l}$.Results of Post Monsoon soil sample indicates that chromium, manganese, iron and nickel were exceeding its permissible limit prescribed by WHO and BIS.Lead exceeds its permissible limit in

16 regions i.e.; $>0.001 \mathrm{mg} / 1$. Due to increase in cadmium content more than drinking water standard will cause damage to lungs, kidney and bone. Whereas nickel causes lung related disease while lead causes weakness, damage kidney and brain. Cobalt causes asthma, cough and wheezing. 


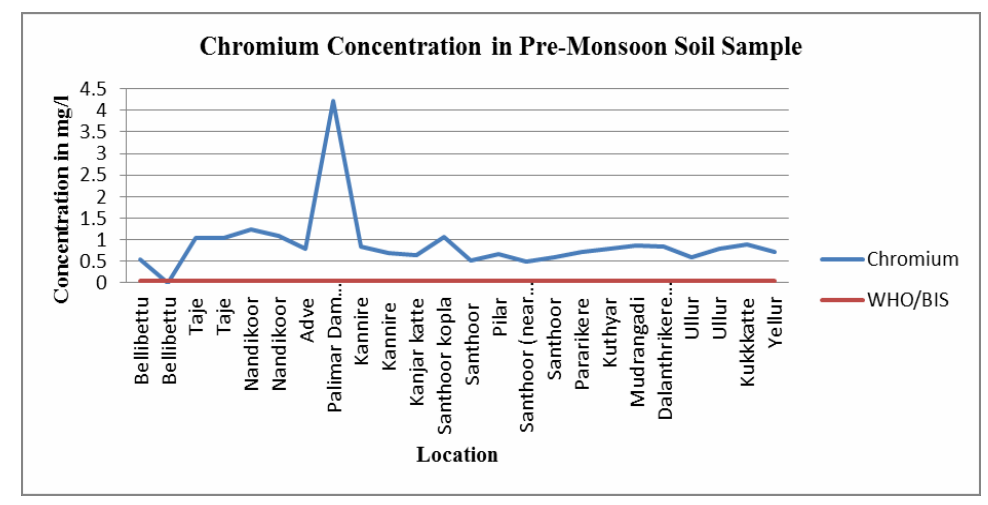

Figure No: 3.2.1 Chromium Concentrations of Pre-Monsoon Soil Samples

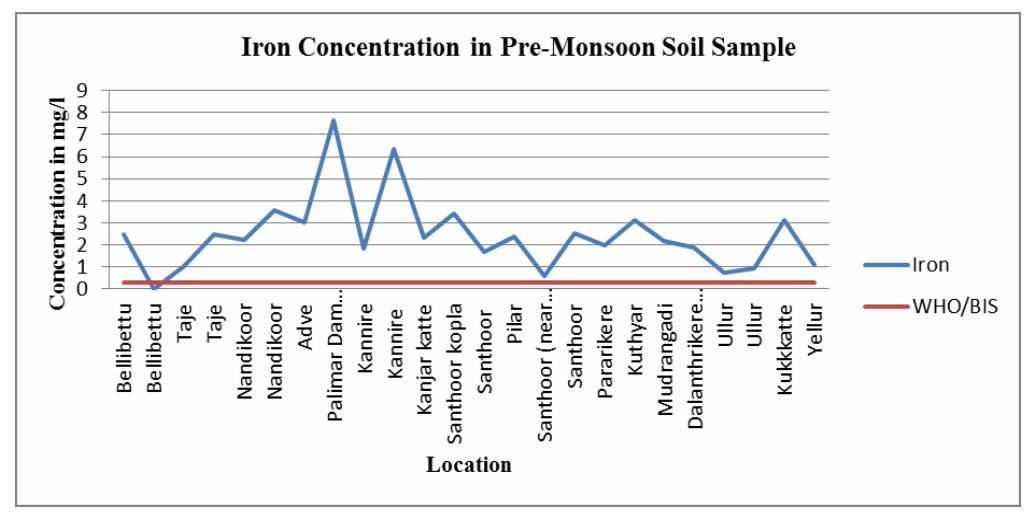

Figure No: 3.2.2 Iron Concentrations of Pre- Monsoon Soil Samples

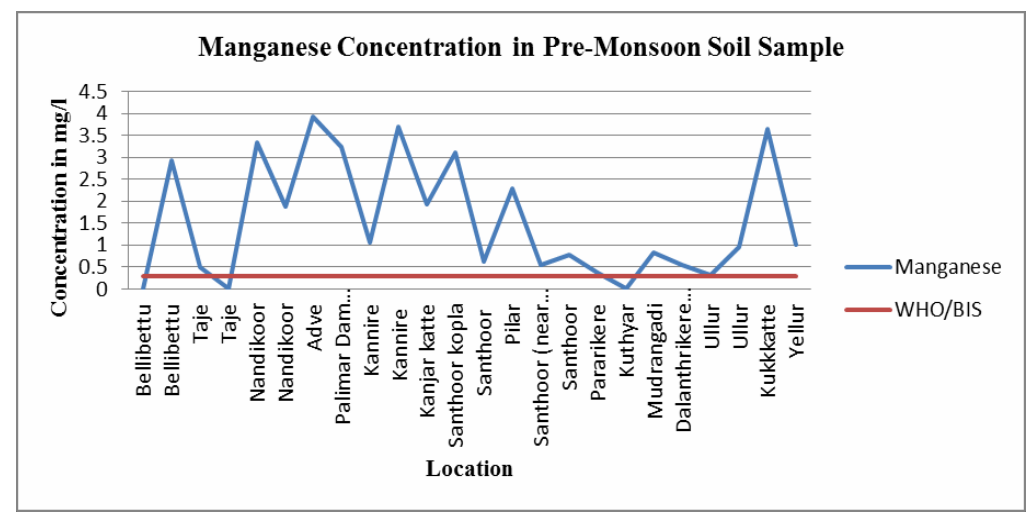

Figure No: 3.2.3 Manganese Concentrations of Pre-Monsoon Soil Samples

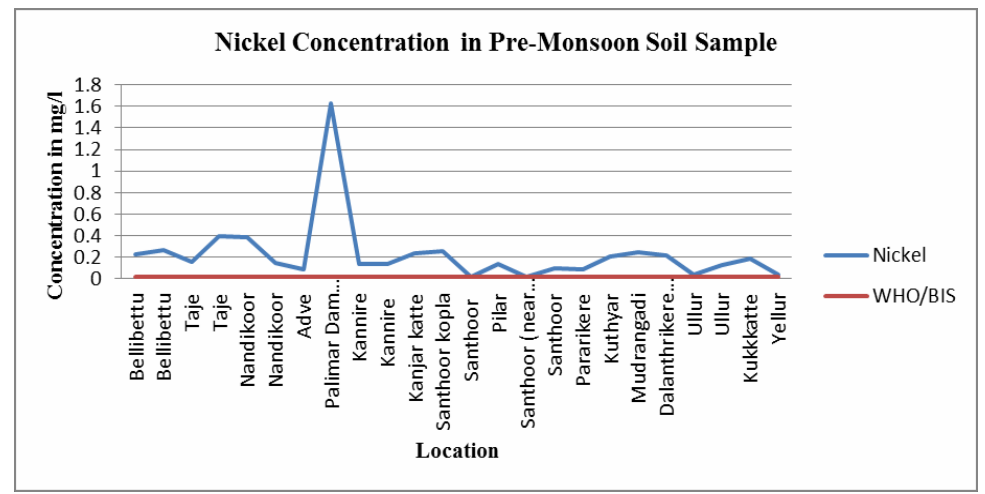

Figure No: 3.2.4 Nickel Concentrations Soil of Pre-Monsoon Samples 


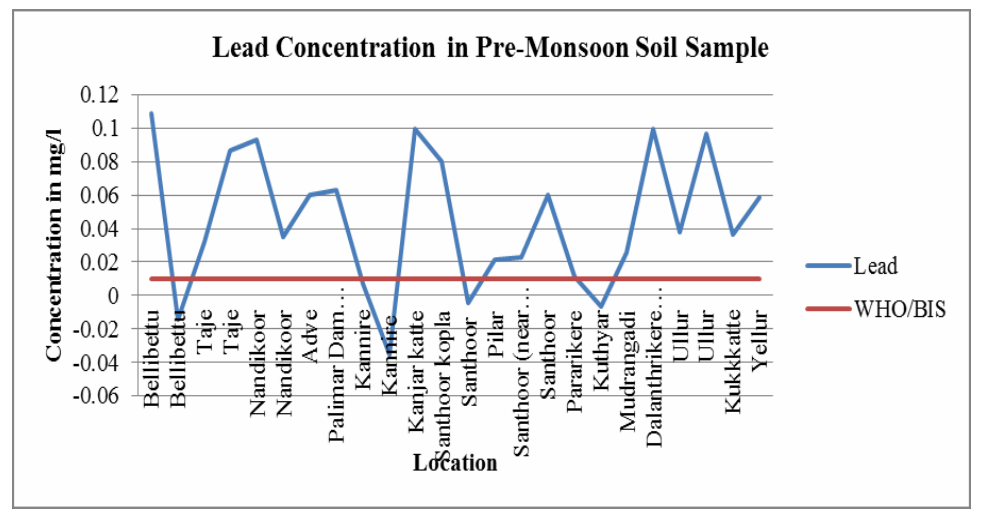

Figure No: 3.2.5 Lead Concentrations of Pre- Monsoon Soil Samples

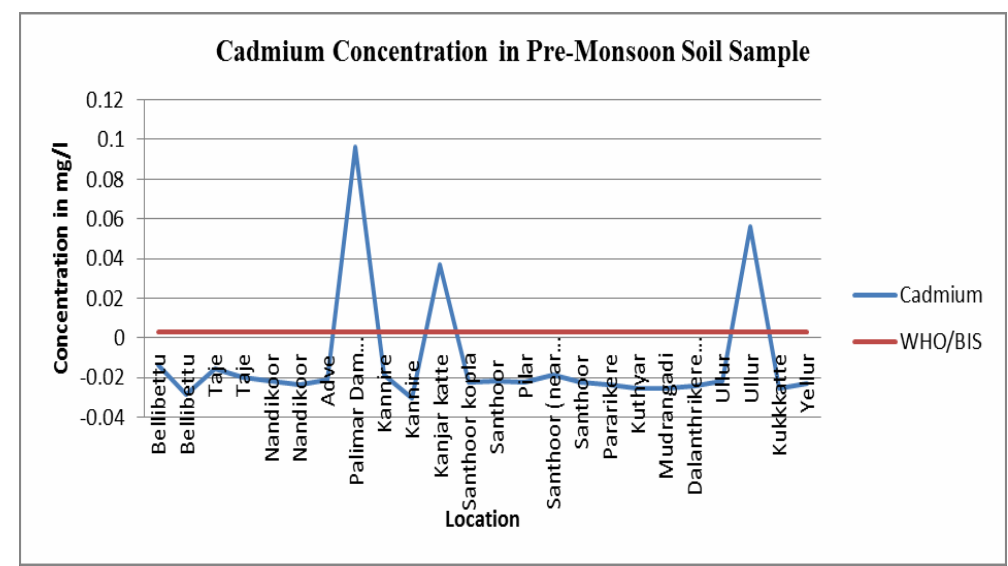

Figure No: 3.2.6 Cadmium Concentrations of Pre-Monsoon Soil Samples

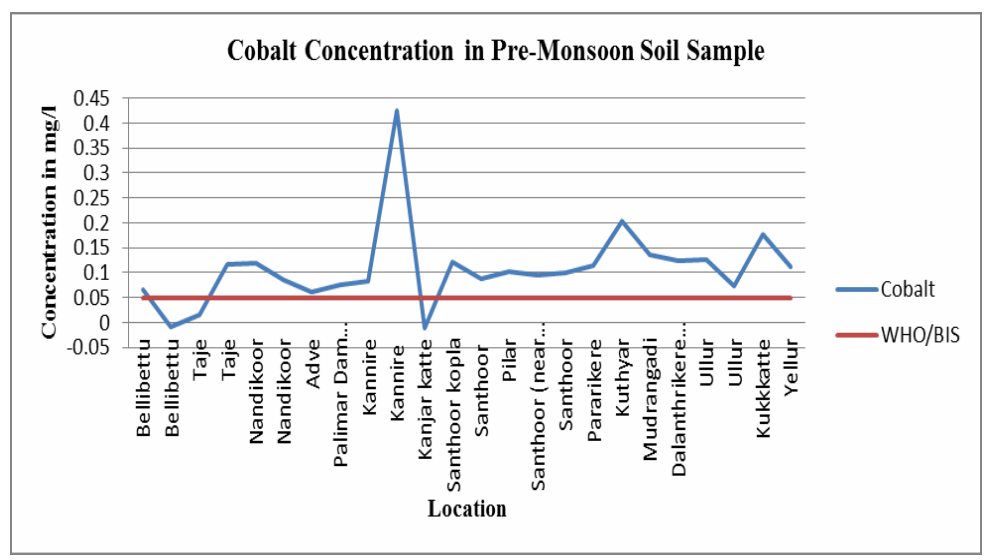

Figure No: 3.2.7 Cobalt Concentrations of Pre- Monsoon Soil Samples

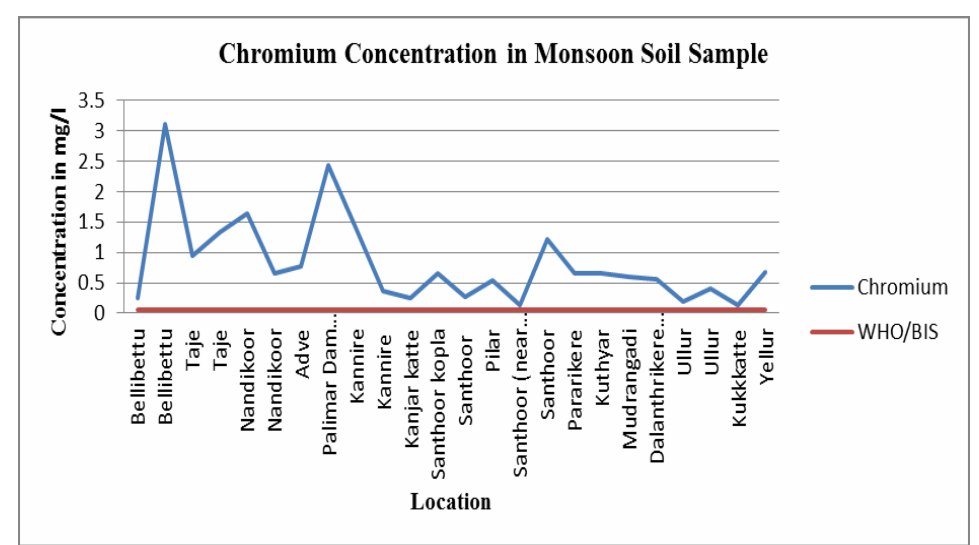

Figure No: 3.2.8 Chromium Concentrations of Monsoon Soil Samples 


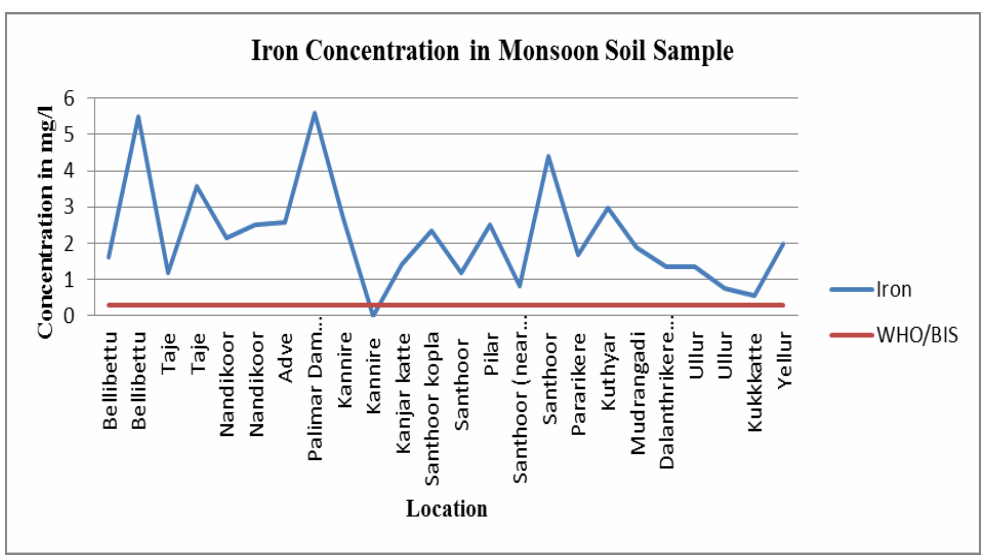

Figure No: 3.2.9 Iron Concentrations of Monsoon Soil Samples

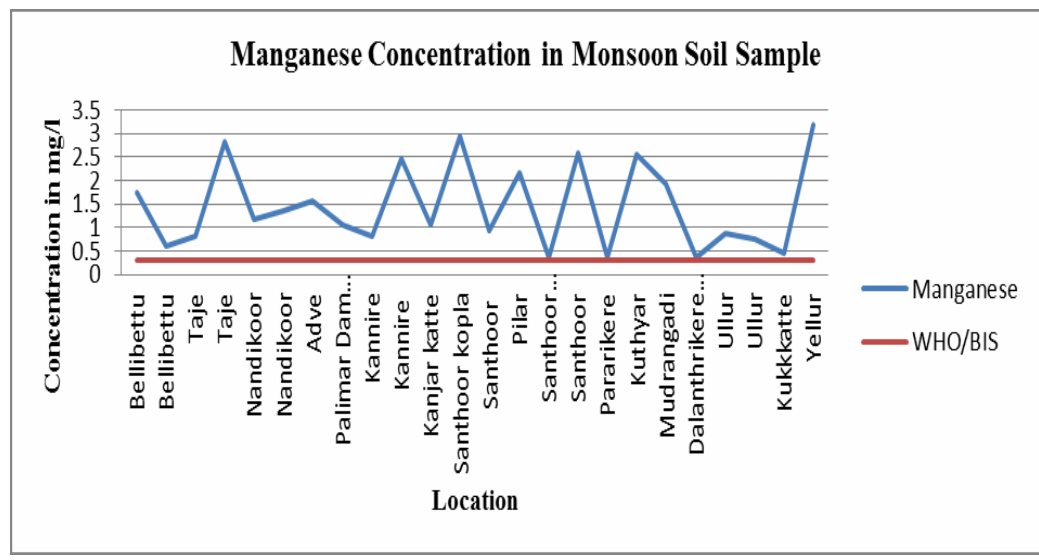

Figure No: 3.2.10 Manganese Concentrations of Monsoon Soil Samples

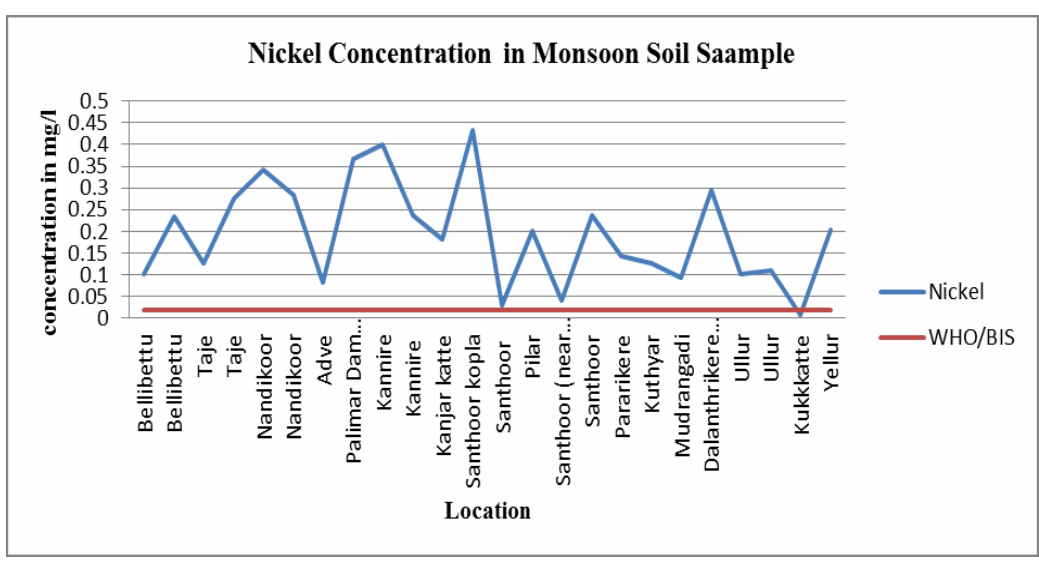

Figure No: 3.2.11 Nickel Concentrations of Monsoon Soil Samples

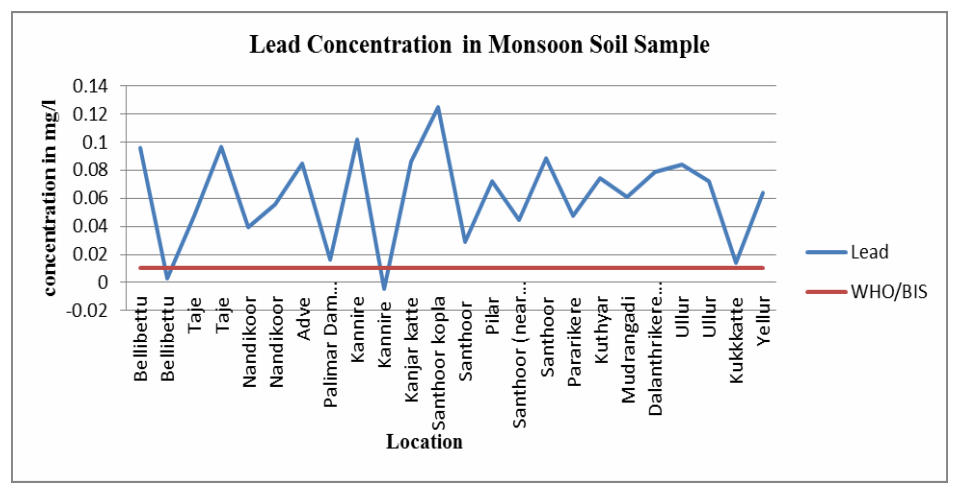

Figure No: 3.2.12 Lead Concentrations of Monsoon Soil Samples 


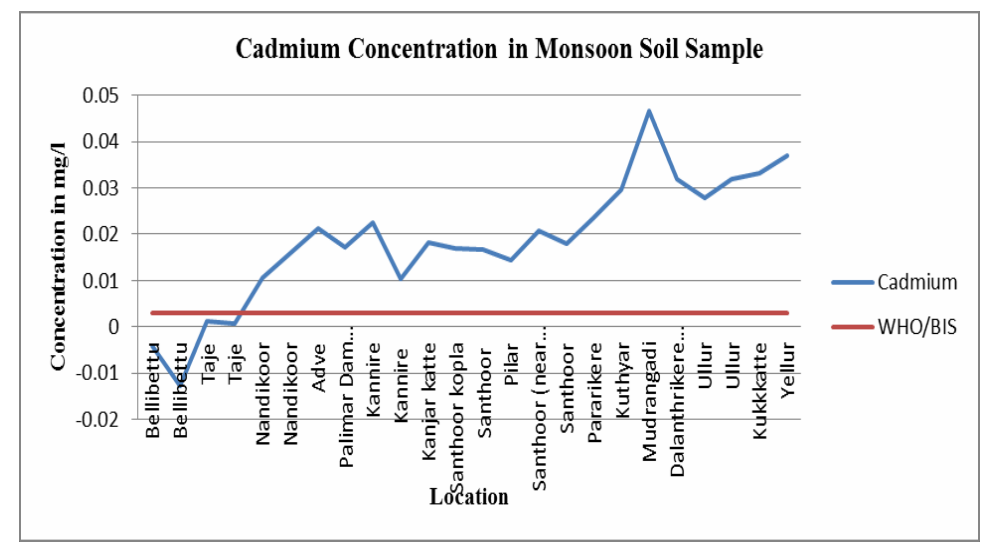

Figure No: 3.2.13 Cadmium Concentrations of Monsoon Soil Samples

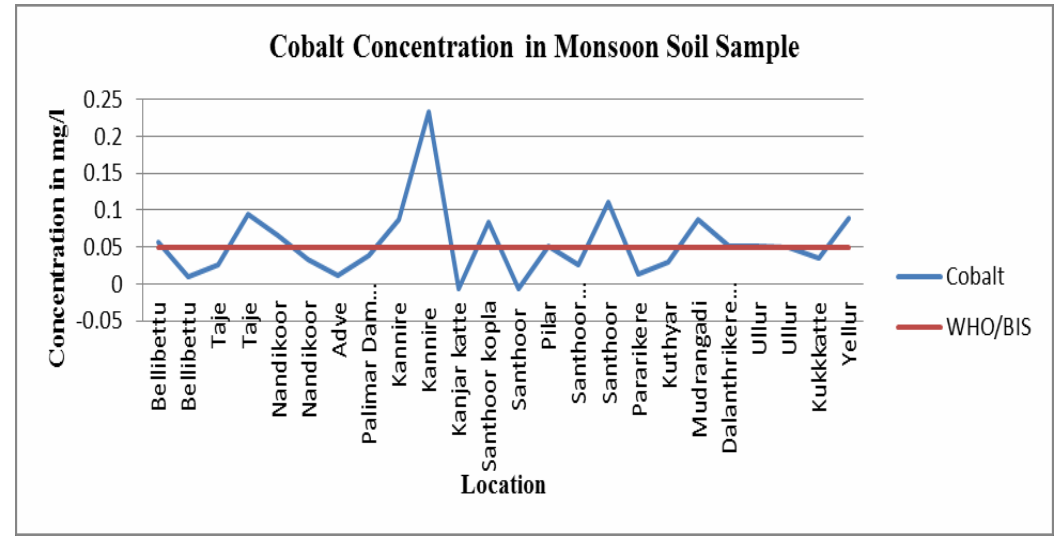

Figure No: 3.2.14 Cobalt Concentrations of Monsoon Soil Samples

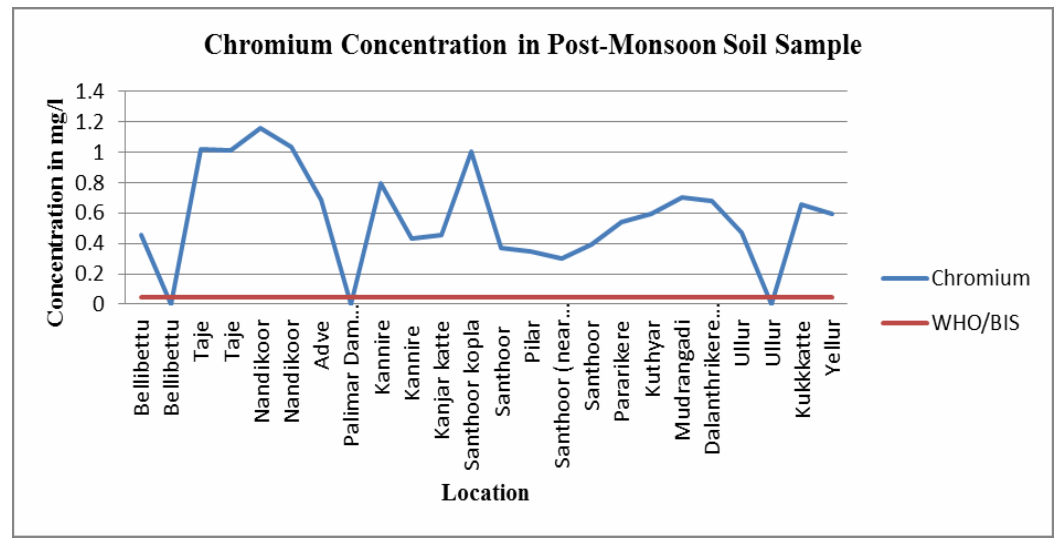

Figure No: 3.2.15 Chromium Concentrations of Post-Monsoon Soil Samples

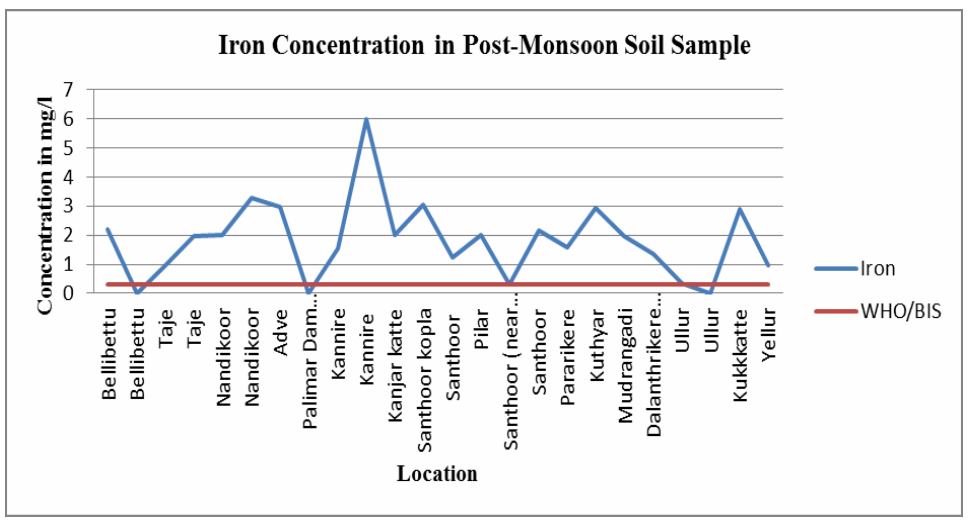

Figure No: 3.2.16 Iron Concentrations of Post- Monsoon Soil Samples 


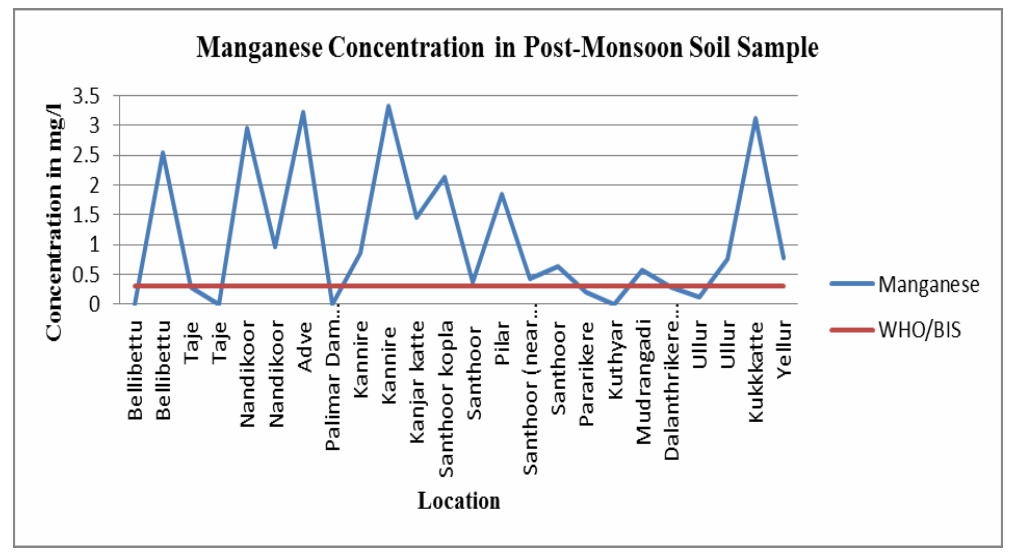

Figure No: 3.2.17 Manganese Concentrations of Post-Monsoon Soil Samples

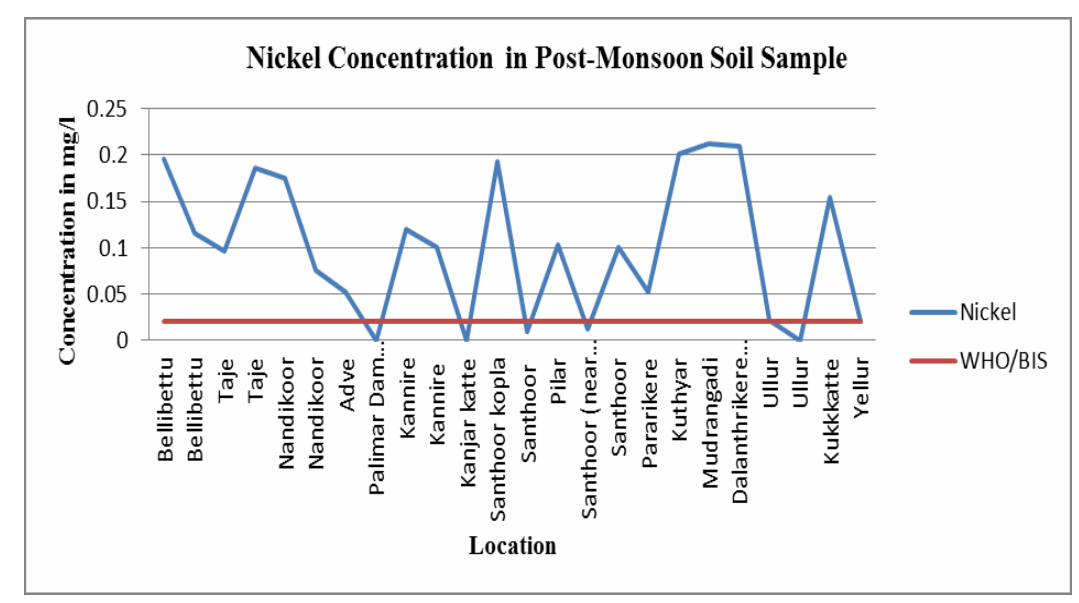

Figure No: 3.2.18 Nickel Concentrations of Post- Monsoon Soil Samples

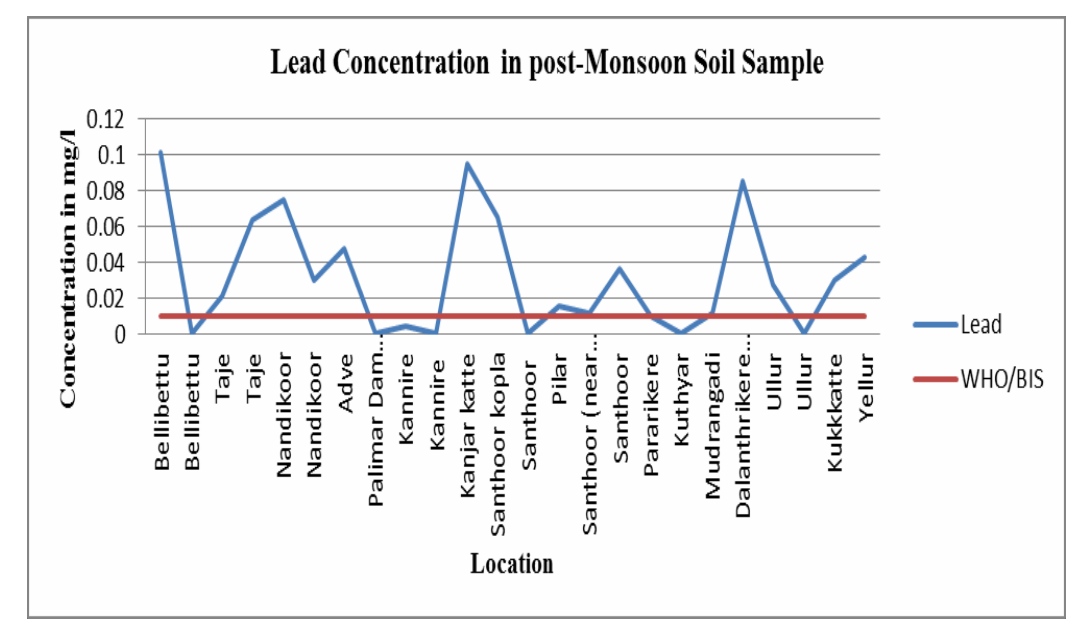

Figure No: 3.2.19 Lead Concentrations of Post- Monsoon Soil Samples 


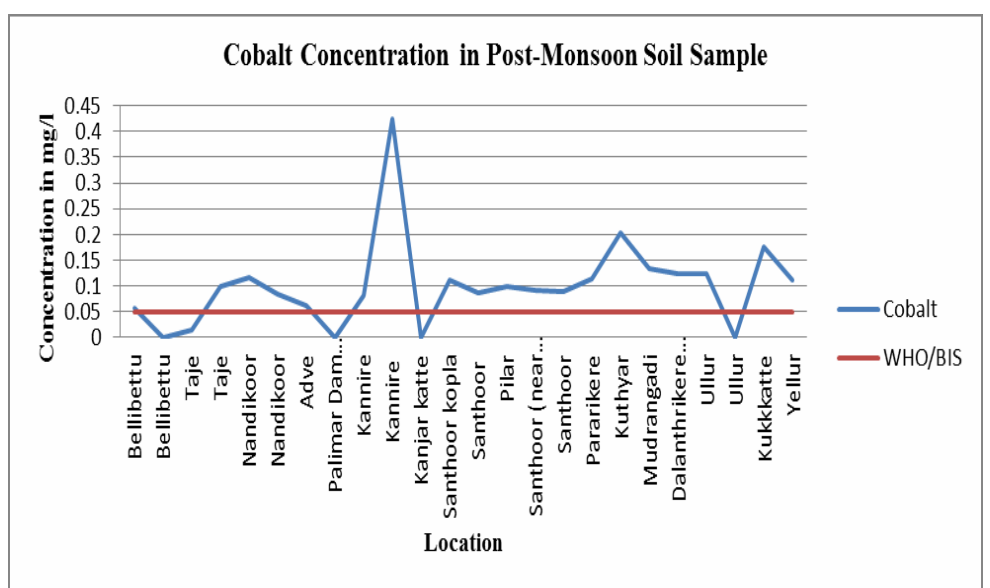

Figure No: 3.2.20 Cobalt Concentrations of Post- Monsoon Soil Samples

\section{Socio-Economic Survey}

A survey conducted to know the environmental impact due to Coal based Thermal Power Plant. We selected different areas which are surrounding the Thermal Power Plant .We prepared the questionnaire and interviewed the people of the localities. From the Socioeconomic survey conducted in several localities found that problems related to Dust accumulation, Respiratory problem, Skin disease and Change of colour in GW sources were observed mainly in Mudrangadi, Santhoor, Kuthyar and Kukkatte.

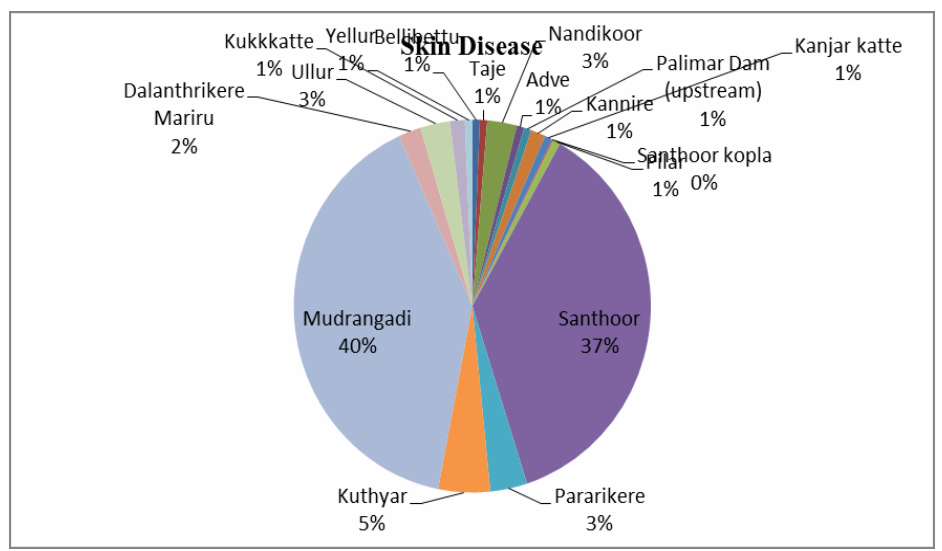

Figure No: 3.3.1 Result of Socio economic survey of Skin disease

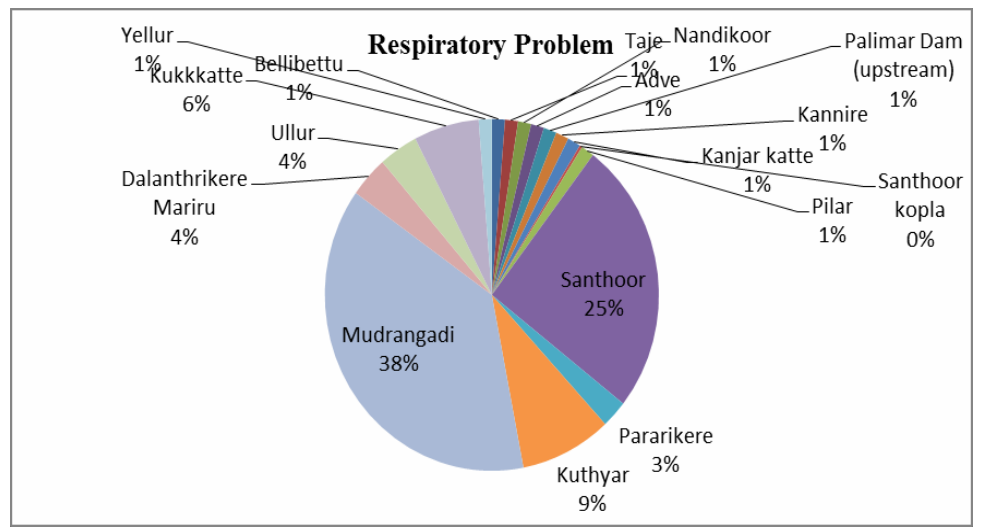

Figure No: 3.3.2 Result of Socio economic survey of Respiratory problem 


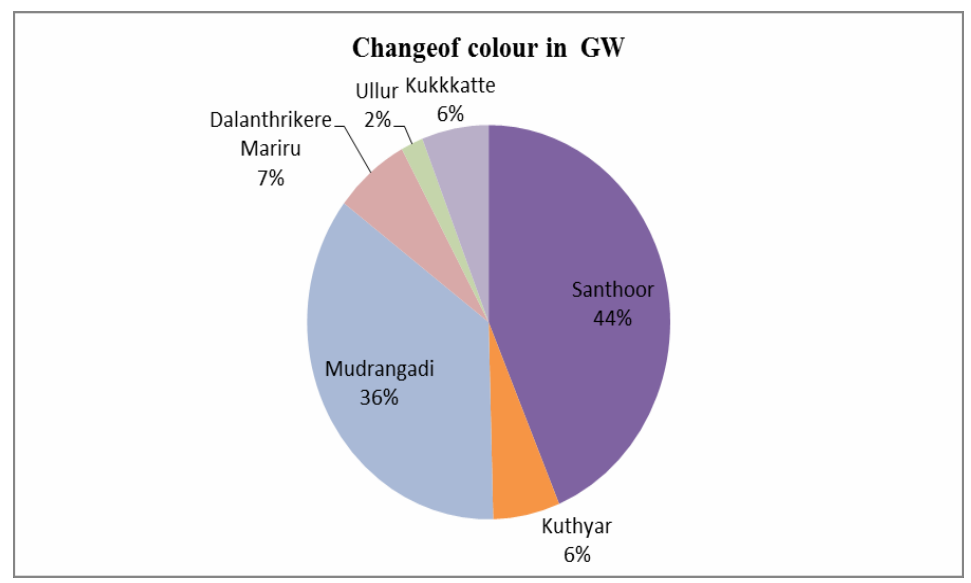

Figure No: 3.3.3 Result of Socio economic survey of Change of colour in GW

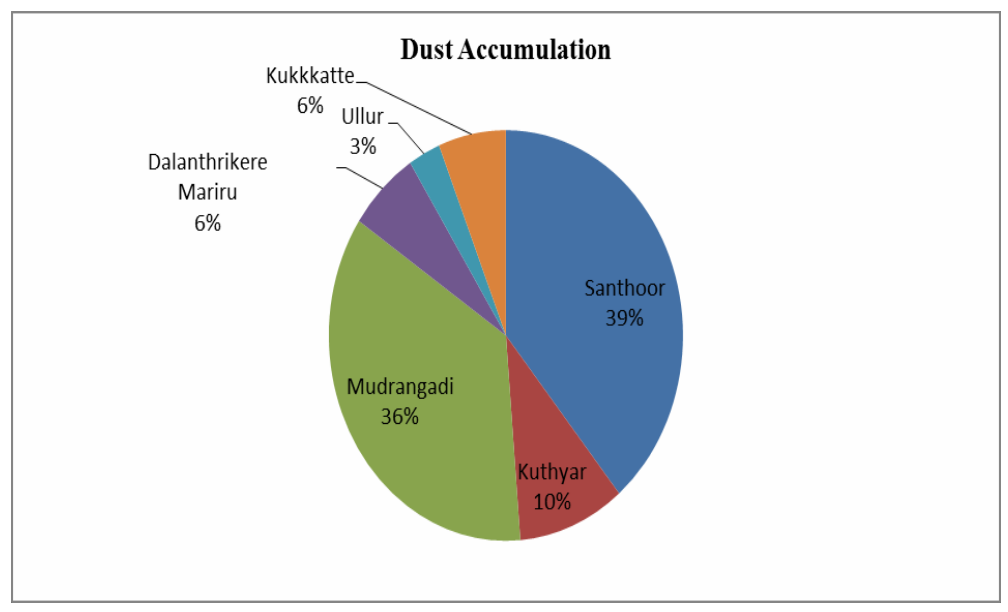

Figure No: 3.3.4 Result of Socio economic survey of Dust Accumulation

\section{Conclusion}

We studied the ground water and soil samples of areas which are surrounding the Coal based Thermal Power plant to trace the heavy metal contamination. From the study conducted and data got from the study we draw the following conclusions:

- Ash pond water leaches some soluble ions which contaminates the ground water sources situated in and around ash pond area.

- Transportation of coal and fly ash which get accumulated on the plants, there by reduced growth of plant.

- Ground water samples collected during different seasons were analysed for various heavy metal concentrations in which some samples were exceeding the permissible limit prescribed for the quality of drinking water. Hence in some areas ground water were unfit for drinking purpose.

- Soil samples which are collected based on seasonal variation were analysed for seven heavy metal concentration, in which some samples were exceeding the permissible limit prescribed by WHO and BIS therefore makes the soil unfit for agricultural activities and other purposes. 
- From the Socio economic survey conducted in and around the thermal power plant concludes that people near power plant were facing the problem of dust contaminants of coal and fly ash which also leads breathing problem, skin allergy and eye irritation. Mainly it affects the ground water sources and change of colour in ground water sources.

\section{References}

1.Verma, S. and., A. (2018). Assessment of water quality around coal-fired thermal power plant, Bathinda (Punjab), India. Journal of Applied and Natural Science, 10(3), pp.915924.

2.Verma, C., Madan, S. and Hussain, A. (2016). Heavy metal contamination of groundwater due to fly ash disposal of coal-fired thermal power plant, Parichha, Jhansi, India. Cogent Engineering, 3(1).

3. Singh, R., Gupta, N. and Guha, B. (2016). Fly Ash Disposal in Ash Ponds: A Threat to Ground Water Contamination. Journal of The Institution of Engineers (India): Series A, 97(3), pp.255-260.

4. Mandal, A. and Sengupta, D. (2006). An assessment of soil contamination due to heavy metals around a coal-fired thermal power plant in India. Environmental Geology, 51(3), pp.409-420.

5.Ramya, S., Deshmukh, V., Khandekar, V., Padmakar, C., SuriNaidu, L., Mahore, P., Pujari, P., Panaskar, D., Labhasetwar, P. and Rao, V. (2012). Assessment of impact of ash ponds on groundwater quality: a case study from Koradi in Central India. Environmental Earth Sciences, 69(7), pp.2437-2450.

6.Baba, A. (2002). Assessment of radioactive contaminants in by-products from Yatagan (Mugla, Turkey) coal-fired power plant. Environmental Geology, 41(8), pp.916-921.

7. Khan, I. and Umar, R. (2019). Environmental risk assessment of coal fly ash on soil and groundwater quality, Aligarh, India. Groundwater for Sustainable Development, 8, pp.346-357.

8.Agrawal, P., Mittal, A., Prakash, R., Kumar, M., Singh, T. and Tripathi, S. (2010). Assessment of Contamination of Soil due to Heavy Metals around Coal Fired Thermal Power Plants at Singrauli Region of India. Bulletin of Environmental Contamination and Toxicology, 85(2), pp.219-223.

9. Singh, H. and Kolay, P. (2008). Analysis of Coal Ash for Trace Elements and their Geoenvironmental Implications. Water, Air, and Soil Pollution, 198(1- 4), pp.87-94.

10. Adappa, S., Tiwari, R., Kamath, R. and Guddattu,

$V$. (2017). Health Effects and Environmental issues in residents around Coal Fired Thermal Power Plant, Padubidris: A cross sectional study. Journal of Environmental and Occupational Science, 6(1), p.8.

11. Gaudino, S., Galas, C., Belli, M., Barbizzi, S., de Zorzi, P., Jacimovicc R., Jeran, Z., Pati, A. and Sansone, U. (2007). The role of different soil sample digestion methods on trace elements analysis: a comparison of ICP-MS and INAA measurement results. Accreditation and Quality Assurance, 12(2) pp.84-93.

12. Gupta, D., Rai, U., Tripathi, R. and Inouhe, M. (2002). Impacts of fly-ash on soil and plant responses. Journal of Plant Research, 115(6), pp.401-409. 
13. Mishra, U. (2004). Environmental impact of coal industry and thermal power plants in India. Journal of Environmental Radioactivity, 72(1-2), pp.35-40.

14.Raja, R., Nayak, A., Shukla, A., Rao, K., Gautam,

P., Lal, B., Tripathi, R., Shahid, M., Panda, B., Kumar, A., Bhattacharyya, P., Bardhan, G., Gupta,

S. and Patra, D. (2015). Impairment of soil health due to fly ash-fugitive dust deposition from coal- fired thermal power plants. Environmental Monitoring and Assessment, 187(11)

15. Sushil, S. and Batra, V. (2006). Analysis of fly ash heavy metal content and disposal in three thermal power plants in India. Fuel, 85(17-18), pp.2676-2679.

16. Uddin, A., Khalid, R., Alaama, M., Abdualkader, A., Kasmuri, A. and Abbas, S. (2016). Comparative study of three digestion methods for elemental analysis in traditional medicine products using atomic absorption spectrometry. Journal of Analytical Science and Technology, 7(1). 